\title{
Brighter Outlook for Technology Assessment
}

by our Washington Correspondent THE fortunes of the hapless Office of Technology Assessment (OTA), which has been afflicted for more than a year by Congressional footdragging and bizarre strokes of bad luck, brightened a little last week. It is now likely that the office could even be in business by the end of the year. But even so, it will end up with only about half the money that its backers originally wanted, it will not be able to get down to much serious work before next summer, and it still has a few dangerous waters to negotiate.

The one bright spot is that a compromise is understood to have been reached last week on a matter which, although entirely unrelated to the OTA, has been holding up funds for the office and even threatening to torpedo it entirely. The matter in question is the west front of the Capitol building.

It was, in fact, exactly a year ago that Congress decided to give itself some badly needed technological expertise by passing a bill to establish the OTA. Designed to provide analysis and advice to Congress on issues and legislation involving science and technology, the office still has no funds, and therefore no director and no staff-in other words, it still does not exist. The problem is that although the OTA bill was passed a year ago, a separate vote is required to provide money for the office, and so far attempts to tack OTA money on to appropriations bills have been spectacularly unsuccessful.

The first such move came last summer, when Senator Edward $M$. Kennedy managed to get the Senate to agree to put $\$ 289,000$ into the supplemental appropriations bill-a bill providing money to a variety of agencies for the 1973 financial year (which ended on June 30). But there was no money in the House version of the bill and the conference committee got bogged down over another matter, namely a provision in the bill forcing President Nixon to stop bombing Cambodia. Eventually, the bill was passed with only a couple of weeks of the financial year to go, and the OTA funding had been dropped because, it was argued, there was not enough time to spend it wisely.

Undaunted, OTA's supporters turned to the appropriations bill which provides funds for Congressional activities in the 1974 financial year, and they again ran into trouble. The Senate version of the bill contains some $\$ 3.9$ million for OTA, but the House version contains

nothing, and the matter has been embroiled in another longstanding dispute, this time over the crumbling west wall of the Capitol. In short, the House bill contains money to extend the wall to make room for more offices, while the Senate version contains money simply to restore the wall. It was feared that the OTA money would get lost in tradeoffs in the conference committee, but the Congressional leadership has apparently now come to an agreement on the west front and it is hoped that a final version of the bill can be passed and signed into law by early November.

In any case, the OTA funds will be reduced by at least a third, since the financial year will by then be four months old. And that would give the office only half of the $\$ 5$ million originally envisaged for its first year of operation. It will, however, allow a director and some staff to be appointed. Emilio Q. Daddario, the former chairman of the House subcommittee on Science, Research and Development, is still a safe bet as director.

Once OTA is off and running, one of the first items on the agenda will be the appointment of an advisory committee to provide policy guidance, and panels

\section{NIH \\ Victory or Veloes}

by our Washington Correspondent IT is now almost certain that President Nixon will veto the appropriations bill which contains money for the National Institutes of Health, when it eventually emerges from the Congressional mill. In June, the House of Representatives added some $\$ 1,300$ million to Nixon's budget request for the departments of Labor and Health, Education and Welfare (HEW), and last week the Senate approved an even larger amount-it added $\$ 1,800$ million to the president's budget. Thus, when a conference committee has sorted out the differences in the two versions of the bill, Congress is sure to end up voting at least $\$ 1,500$ million more than Nixon wants to spend.

Although the bills were passed by large margins - 347 votes to 58 in the House and 79 votes to 9 in the Senateit is questionable whether supporters of the bills could muster the two-thirds majority needed to override a presidential veto in both the House and the Senate. Last year, for example, Nixon twice vetoed HEW appropriations bills of outside experts to study some specific problems. Energy research and development, food technology, ocean resources and solid waste disposal are among the items being considered for the panels to study.

The office already has a 12 -member board, consisting of six Senators and six Congressmen, to establish policies and provide control over its activities. Kennedy has been elected chairman of the board, and John Davis, a congressman from Georgia who succeeded Daddario as chairman of the subcommittee on Science, Research and Development, is the vice-chairman. It has, in fact, been rumoured that part of the OTA's financial troubles have been due to Kennedy's connection with the enterprise-essentially, the reasoning is that some Congressmen are reluctant to provide him with another power base from which to launch a possible Presidential bid. But Congressional staff members concerned with the OTA, in both the House and the Senate, have rejected such an assertion. Whatever the truth of the matter, the delay has certainly diminished Kennedy's influence because his term of office expires at the end of next year.

that had been passed overwhelmingly, but several Republicans bowed to White House pressure, voted to sustain the vetoes, and tipped the balance.

In any case, the bill passed last week by the Senate would add huge helpings to the plate of the National Institutes of Health-it contains $\$ 1,882$ million for the research institutes of $\mathrm{NIH}$, which is some $\$ 350$ million more than the Administration wants to spend, and $\$ 140$ million more than the House voted.

Even if the bill is not vetoed, or if the veto is overridden by Congress, the Administration could simply do what it has done in the past few years-refuse to spend the extra money. A court suit filed last month by sixteen organisations, headed by the National Association for Mental Health, two states and fifteen individuals, could, however, tie its hands in that respect. The suit charges that the Administration acted illegally last year in refusing to spend some $\$ 126$ million voted by Congress for mental health and alcoholism programmes. If the Administration loses the case, it would be forced to release the money immediately, and it would probably not be able to impound funds in the future. 